\title{
MEASUREMENT OF NORMAL KIDNEY LENGTH BY SONOGRAPHY AND ITS RELATION TO AGE, SEX, AND BODY HABITUS
}

\section{Kalpana Purohit ${ }^{* 1}$, Ankita Purohit ${ }^{2}$, Geeta Satpathy ${ }^{3}$.}

${ }^{{ }_{1}}$ Assistant professor, Department of Anatomy, Hind Institute of Medical Sciences, Mau, Ataria, Sitapur, Uttar Pradesh, India.

${ }^{2}$ Tutor cum PG Student, Department of Biochemistry, SCB Medical College, Cuttack, Odisha, India.

${ }^{3}$ Assistant professor, Department of Radiology, Kalinga Institute of Medical Sciences, Bhubaneswar, Odisha, India.

\section{ABSTRACT}

Introduction: Normal kidney length is an important indicator of normal renal function. The length ranges from 9 to $13.5 \mathrm{~cm}$. Kidney sizes are roughly related to patient's size. The assessment of renal size is an integral part of evaluation of renal diseases for both diagnostic and prognostic purposes. Normal renal longitudinal length reflects normal renal function, \& it can be conveniently measured by ultrasonography.

Materials and Methods: The aim of this study is to evaluate the normal range of kidney length by Ultrasonography and its correlation with Age, Sex, Height, \& Weight in normal Indian population. The measurement scale was fixed to the wall to measure height. Weight was measured by a weight machine. The ultrasound image was taken in both lateral decubitus position and the renal length was measured as the maximum bipolar dimension in longitudinal plane.

Observations: The mean length in all Age groups was $94.4 \pm 11.8 \mathrm{~mm}$ of right kidney and $97.4 \pm 12 \mathrm{~mm}$ of left kidney and correlated statistically significantly $(p=0.000)$. The mean length of right kidney in male was $94.7 \pm 13.8 \mathrm{~mm}$, whereas in female it was $94 \pm 9.8 \mathrm{~mm}(p=0.597)$ and that of left side was $98.2 \pm 14 \mathrm{~mm}$ in male and $96.6 \pm 10 \mathrm{~mm}$ $(p=0.343)$ in female, which was statistically not significant.

Discussion: In the present study, there was sharp increase in measurements of length till the age of 20 years and slight increase upto 30 years and thereafter, it remained stable beyond 30 years upto 50 years. In the present study the kidney length was found to be larger on left side in $63.68 \%$, right side in $34.98 \%$ and equal in $1.35 \%$. However the difference of length between Male and Female was not statistically significant in the present study. Conclusion: The length of kidney were smaller than previously reported, is probably a reflection of the relatively small body size of South East Asians than western population. Left kidney was larger than Right kidney. With increase in Height, Weight there was an increasing trend in the length of measurement in both the kidneys which were statistically significant.

KEY WORDS: Kidney length, Ultrasonography, Age, Sex, Height, Weight.

Address for Correspondence: Dr. Kalpana Purohit, Assistant professor, Department of Anatomy, Hind Institute of Medical Sciences, Mau, Ataria, Sitapur, Uttar Pradesh, India.

E-Mail: purohit.kalpana1963@gmail.com

\section{Access this Article online}

\section{Quick Response code}

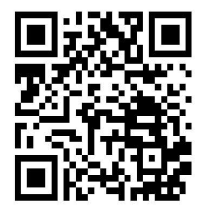

DOI: $10.16965 /$ ijar.2017.432

Web site: International Journal of Anatomy and Research

ISSN 2321-4287

www.ijmhr.org/ijar.htm

Received: 27 Aug 2017

Peer Review: 27 Aug 2017

Revised: 28 Aug 2017
Accepted: 20 Oct 2017

Published (O): 01 Dec 2017

Published (P): 01 Dec 2017
INTRODUCTION

The Kidney is part of the Urinary System and plays an essential role in the regulation of water homeostasis, electrolyte composition, regulation 
of extracellular volume and Acid-Base Homeostasis. It filters the plasma of the blood, \& excretes metabolic waste products from the body [1]. In adults, each kidney is $11 \mathrm{~cm}$ long, $2.5 \mathrm{~cm}$ thick and $5 \mathrm{~cm}$ wide [2]. The length ranges from 9 to $13.5 \mathrm{~cm}$. Kidney sizes are roughly related to patient's size. It is also known that the left kidney is larger than the right kidney $[3,4]$. The assessment of renal size is an integral part of evaluation of renal diseases for both diagnostic and prognostic purposes [5]. Presently Sonography of the kidney has replaced standard Radiography for evaluation of renal diseases $[6,7]$. In individuals with normal renal function, an important measurement of renal size is longitudinal length \& it can be conveniently measured by ultrasonography[8]. Many studies have shown that the renal size measurements are influenced by many factors such as age, ethnicity, gender, weight and height [9-11].

\section{MATERIALS AND METHODS}

The present study is conducted in the Department of Anatomy Kalinga Institute of Medical Sciences, KIIT University, Bhubaneswar, Odisha. Two Hundred (200) Ultrasonography was included of both sex \& all age upto 70 years of age. Multiple Renal Cysts, Polycystic Kidney Disease, Unilateral Kidney, Chronic Kidney Disease or Malignancy, previous renal surgery or any congenital anomaly were excluded from this study. To measure height, the measurement scale was fixed to the wall. Height was measured while the subject stood without shoes or hat with heels, buttocks, shoulders and occiput touching the vertical scale $\&$ the head held upright. The standing height was measured on a stadiometer in children above 2 years $\&$ in children below 2 years the supine lengths were measured on an Infantometer. Height was measured on rounded to the nearest $0.5 \mathrm{~cm}$. weight was taken in a weighing machine. The ultrasound image was taken in both lateral decubitus position and also instructed to hold their breath for a short while. After locating the Kidney, the transducer was rotated slightly to determine the longest renal axis and the renal length was measured as the maximum bipolar dimension in longitudinal plane which was displaying better Central Sinus Echoes, with the renal parenchyma evenly distributed around the Central Sinus.

Fig. 1: Figure showing measurement of length of kidney.

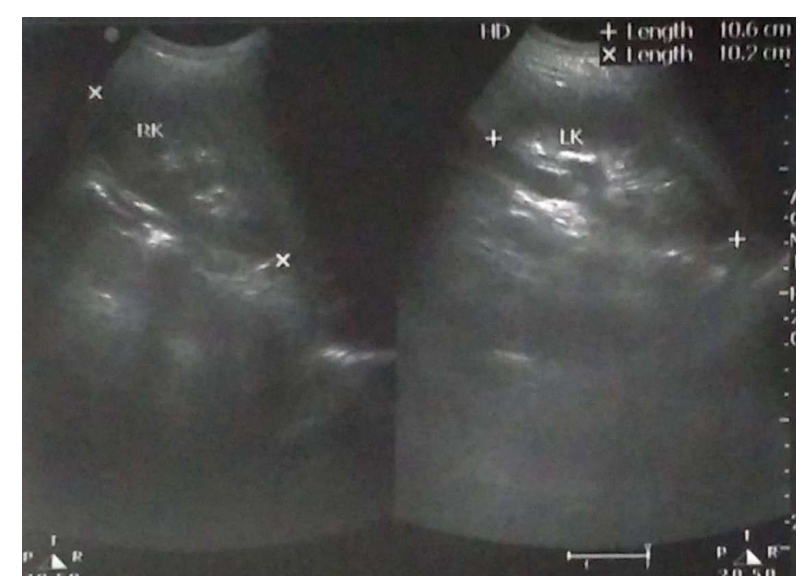

\section{OBSERVATIONS}

Data analysis was done by using software SPSS 13 version. The analysis of the age parameters by ten years age group was conducted through an ANOVA. The mean length in all age groups of right kidney was $94.4 \pm 11.8 \mathrm{~mm}$ and correlated statistically significantly $(p=0.000)$. The mean length in d"10 year age group was $75.2 \pm 11.7 \mathrm{~mm}$ with a sharp increase to $98.2 \pm 9.2 \mathrm{~mm}$ upto 21-30 years of age. Thereafter, the mean length remained almost constant upto $41-50$ years i.e. $99 \pm 8.6 \mathrm{~mm}$. There was a declining trend after 50 years of age upto 70 years of age $(95.5 \pm 9.4 \mathrm{~mm})$. The mean length in all age groups of left kidney was $97.4 \pm 12 \mathrm{~mm}$ and correlated statistically significantly $(p=0.000)$. The mean length in $d " 10$ year age group was $76.6 \pm 9.8 \mathrm{~mm}$, increased upto $41-50$ years age group $(103.2 \pm 10.1 \mathrm{~mm})$. After that there was a declining trend upto 70 years (Table 1).

It was found (of' $t$ ' test) that male kidney were larger than female kidney in both sides. The mean length of right kidney in male was $94.7 \pm 13.8 \mathrm{~mm}$, whereas in female it was $94 \pm 9.8 \mathrm{~mm}(p=0.597)$ and that of left side was $98.2 \pm 14 \mathrm{~mm}$ in male and $96.6 \pm 10 \mathrm{~mm}(p=0.343)$ in female, which was statistically not significant (Table 2).

There was significant difference $(p=0.000)$ of the length of both right and left kidneys among the Weight groups. The analysis revealed that, as the weight increases the length of kidney also increases (Table 3).

The subjects were classified into four groups on 
Table 1: Descriptive Statistics and ANOVA for Parameters of Right and Left Kidney by Age Group by USG.

\begin{tabular}{|c|c|c|c|c|c|c|c|c|c|}
\hline & \multirow{2}{*}{$\begin{array}{c}\text { Age Group } \\
\text { (years) }\end{array}$} & \multirow{2}{*}{$\mathbf{N}$} & \multirow{2}{*}{ Mean } & \multirow{2}{*}{$\begin{array}{c}\text { Std. } \\
\text { Deviation }\end{array}$} & \multicolumn{2}{|c|}{$\begin{array}{l}\text { 95\% Confidence } \\
\text { Interval for Mean }\end{array}$} & \multirow{2}{*}{ Min } & \multirow{2}{*}{ Max } & \multirow{2}{*}{ f \& p Value } \\
\hline & & & & & $\begin{array}{l}\text { Lower } \\
\text { Bound }\end{array}$ & $\begin{array}{l}\text { Upper } \\
\text { Bound }\end{array}$ & & & \\
\hline \multirow{8}{*}{$\begin{array}{l}\text { Length Right } \\
\text { Kidney (mm) }\end{array}$} & $\leq 10$ & 26 & 75.208 & 11.679 & 70.491 & 79.925 & 55.3 & 97.7 & \multirow{4}{*}{21.27} \\
\hline & $11-20$ & 36 & 94.048 & 9.25 & 91.165 & 96.93 & 72.7 & 109.4 & \\
\hline & $21-30$ & 35 & 98.152 & 9.201 & 95.48 & 100.824 & 80.4 & 119.5 & \\
\hline & $31-40$ & 38 & 97.926 & 10.167 & 94.758 & 101.094 & 78.7 & 120.1 & \\
\hline & $41-50$ & 28 & 99.043 & 8.6 & 95.708 & 102.378 & 84.4 & 122.7 & \multirow{4}{*}{0} \\
\hline & $51-60$ & 18 & 96.439 & 6.333 & 93.29 & 99.588 & 80.7 & 110.5 & \\
\hline & $61-70$ & 19 & 95.542 & 9.493 & 90.967 & 100.117 & 78.9 & 113.5 & \\
\hline & Total & 200 & 94.413 & 11.801 & 92.855 & 95.97 & 55.3 & 122.7 & \\
\hline \multirow{8}{*}{$\begin{array}{l}\text { Length Left } \\
\text { Kidney (mm) }\end{array}$} & $\leq 10$ & 26 & 76.623 & 9.812 & 72.66 & 80.586 & 56.6 & 95.3 & \multirow{4}{*}{26.141} \\
\hline & Nov-20 & 36 & 96.864 & 9.901 & 93.779 & 99.95 & 69.5 & 121 & \\
\hline & $21-30$ & 35 & 101.719 & 8.642 & 99.209 & 104.228 & 82.2 & 120.7 & \\
\hline & $31-40$ & 38 & 100.783 & 9.815 & 97.725 & 103.842 & 78.1 & 121.9 & \\
\hline & 41- 50 & 28 & 103.236 & 10.147 & 99.301 & 107.17 & 87.1 & 136.8 & \multirow{4}{*}{0} \\
\hline & $51-60$ & 18 & 99.494 & 5.312 & 96.853 & 102.136 & 89.2 & 111.1 & \\
\hline & $61-70$ & 19 & 97.458 & 9.556 & 92.852 & 102.064 & 81.4 & 118.5 & \\
\hline & Total & 200 & 97.35 & 12.087 & 95.755 & 98.945 & 56.6 & 136.8 & \\
\hline
\end{tabular}

Table 2: Comparison of Parameters of Right and Left Kidney by Sex by USG.

\begin{tabular}{|c|c|c|c|c|c|c|c|c|c|}
\hline \multirow{2}{*}{ Group Statistics } & \multirow{2}{*}{ Sex } & \multirow{2}{*}{$\mathbf{N}$} & \multirow{2}{*}{ Mean } & \multirow{2}{*}{$\begin{array}{c}\text { Std. } \\
\text { Deviation }\end{array}$} & \multirow{2}{*}{$\begin{array}{l}\text { Std. Error } \\
\text { Mean }\end{array}$} & \multicolumn{2}{|c|}{$\begin{array}{l}\text { 95\% Confidence } \\
\text { Interval for Mean }\end{array}$} & \multirow{2}{*}{ t Value } & \multirow{2}{*}{ p Value } \\
\hline & & & & & & $\begin{array}{l}\text { Lower } \\
\text { Bound }\end{array}$ & $\begin{array}{l}\text { Upper } \\
\text { Bound }\end{array}$ & & \\
\hline \multirow{2}{*}{$\begin{array}{l}\text { Length Right } \\
\text { Kidney (mm) }\end{array}$} & $M$ & 105 & 94.866 & 13.777 & 1.345 & 92.23 & 97.501 & \multirow{2}{*}{0.53} & \multirow{2}{*}{0.597} \\
\hline & $F$ & 95 & 94.009 & 9.757 & 0.898 & 92.249 & 95.77 & & \\
\hline \multirow{2}{*}{$\begin{array}{l}\text { Length Left } \\
\text { Kidney (mm) }\end{array}$} & $M$ & 105 & 98.181 & 14.052 & 1.371 & 95.493 & 100.869 & \multirow{2}{*}{0.95} & \multirow{2}{*}{0.343} \\
\hline & $F$ & 95 & 96.611 & 10.026 & 0.923 & 94.802 & 98.42 & & \\
\hline
\end{tabular}

Table 3: Descriptive Statistics and ANOVA for Parameters of Right and Left Kidney by eight(kg) by USG.

\begin{tabular}{|c|c|c|c|c|c|c|c|}
\hline & \multirow{2}{*}{$\begin{array}{l}\text { Weight } \\
\text { Groups }\end{array}$} & \multirow{2}{*}{ Mean } & \multirow{2}{*}{$\begin{array}{c}\text { Std. } \\
\text { Deviation }\end{array}$} & \multicolumn{2}{|c|}{$\begin{array}{l}\text { 95\% Confidence } \\
\text { Interval for Mean }\end{array}$} & \multirow{2}{*}{ f value } & \multirow{2}{*}{$p$ value } \\
\hline & & & & $\begin{array}{l}\text { Lower } \\
\text { Bound }\end{array}$ & $\begin{array}{l}\text { Upper } \\
\text { Bound }\end{array}$ & & \\
\hline \multirow{7}{*}{$\begin{array}{l}\text { Length Right } \\
\text { Kidney (mm) }\end{array}$} & $\leq 30$ & 75.663 & 11.186 & 71.486 & 79.84 & \multirow{7}{*}{47.462} & \multirow{7}{*}{0} \\
\hline & $31-40$ & 89.944 & 7.878 & 86.828 & 93.061 & & \\
\hline & $41-50$ & 95.732 & 5.683 & 94.063 & 97.401 & & \\
\hline & $51-60$ & 96.401 & 8.647 & 94.308 & 98.495 & & \\
\hline & $61-70$ & 103.021 & 7.304 & 100.472 & 105.569 & & \\
\hline & $>70$ & 105.776 & 8.909 & 101.196 & 110.357 & & \\
\hline & Total & 94.413 & 11.801 & 92.855 & 95.97 & & \\
\hline \multirow{7}{*}{$\begin{array}{l}\text { Length Left } \\
\text { Kidney (mm) }\end{array}$} & $\leq 30$ & 77.883 & 10.458 & 73.978 & 81.788 & \multirow{6}{*}{42.406} & \multirow{6}{*}{0} \\
\hline & $31-40$ & 95.552 & 8.187 & 92.313 & 98.79 & & \\
\hline & $41-50$ & 97.557 & 8.448 & 95.077 & 100.038 & & \\
\hline & $51-60$ & 99.919 & 8.358 & 97.896 & 101.942 & & \\
\hline & $61-70$ & 104.794 & 7.791 & 102.076 & 107.513 & & \\
\hline & $>70$ & 108.824 & 9.759 & 103.806 & 113.841 & & \\
\hline & Total & 97.35 & 12.087 & 95.755 & 98.945 & 25.788 & 0 \\
\hline
\end{tabular}


Table 4: Descriptive Statistics and ANOVA for Parameters of Right and Left Kidney by Height (cms) by USG

\begin{tabular}{|c|c|c|c|c|c|c|}
\hline & \multirow{2}{*}{ Height Groups } & \multirow{2}{*}{ Mean } & \multirow{2}{*}{$\begin{array}{c}\text { Std. } \\
\text { Deviation }\end{array}$} & \multicolumn{2}{|c|}{$\begin{array}{l}\text { 95\% Confidence Interval for } \\
\text { Mean }\end{array}$} & \multirow{2}{*}{ F \& P Value } \\
\hline & & & & Lower Bound & $\begin{array}{l}\text { Upper } \\
\text { Bound }\end{array}$ & \\
\hline \multirow{5}{*}{$\begin{array}{l}\text { Length Right } \\
\text { Kidney (mm) }\end{array}$} & $\leq 130$ & 75.104 & 11.558 & 70.333 & 79.875 & \multirow{3}{*}{48.671} \\
\hline & $131-150$ & 93.917 & 8.609 & 91.521 & 96.314 & \\
\hline & $151-170$ & 96.743 & 9.195 & 95.108 & 98.377 & \\
\hline & $>170$ & 105.076 & 7.479 & 101.672 & 108.481 & \multirow{2}{*}{0} \\
\hline & Total & 94.432 & 11.824 & 92.868 & 95.996 & \\
\hline \multirow{5}{*}{$\begin{array}{l}\text { Length Left } \\
\text { Kidney (mm) }\end{array}$} & $\leq 130$ & 76.12 & 9.718 & 72.109 & 80.131 & \multirow{3}{*}{55.924} \\
\hline & $131-150$ & 96.729 & 8.665 & 94.316 & 99.141 & \\
\hline & $151-170$ & 100.406 & 8.957 & 98.813 & 101.998 & \\
\hline & $>170$ & 106.233 & 10.863 & 101.289 & 111.178 & \multirow{2}{*}{0} \\
\hline & Total & 97.361 & 12.113 & 95.759 & 98.963 & \\
\hline
\end{tabular}

the basis of their Height. The groups were yielded comparable results with kidney length $\leq 130 \mathrm{~cm}, 131-150 \mathrm{~cm}, 151-170 \mathrm{~cm}$ and $>170 \mathrm{~cm}$.

The mean of length of right and left kidney along with ANOVA results according to Height has been furnished in Table 4. There is an increasing trend of the length of kidney with the Height, which was statistically significant $(p=0.000)$.

\section{DISCUSSION}

Ultrasound is the preferred method of diagnosis in most clinical practice. Ultrasonographic renal size is one of the easily reproducible parameter and provides a rough indication of the renal function. The minimal size of a fully functional kidney is $9 \mathrm{~cm}$ in length[12]. A difference in length of $2 \mathrm{~cm}$ or more between the right $\&$ left kidneys may raise the possibility of unilateral kidney disease. Many congenital and acquired diseases directly or indirectly affect renal dimensions in all age groups[3]. Decrease in size and function are seen with chronic renal failure[13], renal arterial occlusion[14] and late stage renal venous thrombosis[15]. Autopsy findings of renal biometry in Indian population ranging between 9.1-9.9cm [16, 18]. However, reported lengths obtained during dedicated renal ultrasound examinations were both more accurate and more precise than those reported in general abdominal ultrasound examinations. In the present study the mean kidney length correlated with the previous studies of Adeela Arooj et al (2011)[17], Zeb Saeed et al (2012)[18], Mujahid Raza et al (2011)[19], J.O. Carrasco etal (2009)[3], Buchholz NP et al (2000)[20]. The smaller length of kidney, probably due to reflection of the relatively small body size of South East Asians[18, 20].

In the present study the kidney length was found to be larger on left side in $63.68 \%$, right side in $34.98 \%$ and equal in 1.35\%. E. Dinkel et al (1985), in their study observed that Left kidney in children were slightly greater in median length $(0.9 \mathrm{~mm})$ and median volume $(2.5 \mathrm{ml})$ than Right kidney. The kidney was found to be longer on the Left in $51.7 \%$, on the Right in $34.1 \%$ and of equal size in $14.2 \%[21]$.

Table 5: Kidney length in different studies.

\begin{tabular}{|c|c|c|c|c|c|c|c|}
\hline & Parameter & $\begin{array}{c}\text { Present } \\
\text { Study }\end{array}$ & $\begin{array}{c}\text { Adeela Arooj } \\
\text { (2011) }\end{array}$ & $\begin{array}{c}\text { Zeb Saeed } \\
\text { (2012) }\end{array}$ & $\begin{array}{c}\text { Mujahid Raza } \\
\text { (2011) }\end{array}$ & $\begin{array}{c}\text { J.O. Carrasco } \\
\text { (2009) }\end{array}$ & $\begin{array}{c}\text { Buchholz NP } \\
\text { (2000) }\end{array}$ \\
\hline Right kidney & Length (mm) & $94.4 \pm 11.8$ & $97 \pm 7.9$ & 98.5 & $101.6 \pm 8.9$ & $104.3 \pm 6.4$ & $104 \pm 9$ \\
\hline Left kidney & Length $(\mathrm{mm})$ & $97.3 \pm 12.0$ & $99 \pm 9.6$ & 100 & $102.7 \pm 9.2$ & $105.8 \pm 7$ & $105 \pm 9$ \\
\hline
\end{tabular}

Table 6: Percentage Distribution Of Kidney Length.

\begin{tabular}{|c|c|c|}
\hline & $\begin{array}{c}\text { PRESENT } \\
\text { STUDY }\end{array}$ & E. DINKEL (1985) \\
\hline Left length larger & $63.68 \%$ & $51.70 \%$ \\
\hline Right length larger & $34.98 \%$ & $34.10 \%$ \\
\hline Equal length & $1.35 \%$ & $14.20 \%$ \\
\hline
\end{tabular}


In the present study, there was sharp increase in measurements of length till the age of 20 years and slight increase upto 30 years and thereafter, it remained stable beyond 30 years upto 50 years. A. Hekmatnia, M. Yaraghi (2004) got significant decrease in absolute and relative renal length in the age group 60-69 years old. They showed gradual decrease in renal length with increase in age and the decrease accelerates after the age of sixty years[22]. However the difference of length between male and female was not statistically significant in the present study. In this present study all the length of kidney correlates well with Height, Weight and statistically significantly $(p=0.000)$. Higher body weight and height requires a bigger kidney[17] E. Dinkel et al (1985) found better correlation between kidney length to body height than to age or body weight[21].

\section{CONCLUSION}

The length of kidney in this study were smaller than previously reported, is probably a reflection of the relatively small body size of South East Asians than western population. Left kidney was larger than Right kidney. With increase in Height, Weight there was an increasing trend in the length of measurement in both the kidneys which were statistically significant.

\section{Conflicts of Interests: None}

\section{REFERENCES}

[1]. Barrett Kim E., Susan M. Barman, Scott Boitano, Heddwen L. Brooks, Ganong's Review of medical physiology, $24^{\text {th }}$ edition, page 671 .

[2]. Rumack Carol M., Stephanie R. Wilson, J. William, Charboneau. Textbook of Diagnostic Ultrasound- $3^{\text {rd }}$ edition (2005), volume 1, page 322.

[3]. Oyuela-Carrasco Justo, Franciso RodriguezCastellanos, Eric Kimura, Rosa Elena Delgado, Juan Pablo Herrera-Felix. Renal length by ultrasound in Mexican adults. Nefrologia 2009; 29 (1):30-34.

[4]. Fernandes Mario M. R., Carla C. S. Lemos, Guilherme S. lopes, Eugenio P. Q. Madeira, Omar R. Santos, David Dorigo, Raquel Bregman. Normal renal dimensions in a specific population. Int Braz J Urol. 2002; Vol 28(6):510-515.

[5]. Otiv A., K Mehta, U Ali and M Nadkarni. Sonographic Measurement of Renal Size in Normal Indian Children. Indian Paediatrics. 2012:1-4.

[6]. Emamian Seyed A., Michael B. Nielsen, Jan F. Pedersen, Lars Ytte. Kidney dimensions at sonography: Correlation with age, sex, and habitus in 665 adult volunteers. Am J Roentgenol. 1993; 160:83-86
[7]. Gourtsoyiannis Nicholas, Panos Prassopoulos, Dionisis Cavouras, Nicholas Pantelidis. The Thickness of the Renal Parenchyma Decreases with Age: A CT Study of 360 Patients. AJR1990; 155: 541-544.

[8]. Mazzotta L, Sarteschi LM, Carlini A, Antonelli A. Comparison of renal ultrasonographic and functional biometry in healthy patients and in patients with chronic renal failure. Arch Ital Urol Androl 2002;74:206-9. Cited by Mujahid Raza et al. J Ayub Med Coll Abbottabad 2011.

[9]. Chen J.J., J. Pugach, M. Patel, A. Luisiri and G.F. Steinhardt, 2002. The renal length nomogram: a multivariate approach. J Urology. Vol. 168:21492152. Cited by Adeela Arooj et al. International journal of biology and biomedical engineering, 2011.

[10]. Chen J.J., Jizu Zhi, Wenyang Mao and G.F. Steinhardt, 2006. Nomogram: A web-based multivariable pediatric renal nomogram. Journal of Paediatric Radiology. Vol. 2 (5): 436-438. Cited by Adeela Arooj et al. International journal of biology and biomedical engineering, 2011.

[11]. Elkin M. Radiology of the urinary system. Boston, Little, Brown and company. Kidney size, In Elkin M (ed.), 1980; 1014-1032. Cited by Adeela Arooj et al. International journal of biology and biomedical engineering, 2011.

[12]. Ablett MJ, Coulthard A, Lee RE, Richardson DL, Bellas $\mathrm{T}$, Owen JP et al. How reliable are ultrasound measurements of renal length in adults? Br J Radiol. 1995;68:1087-1089. Cited by Ho Sik Shin et al Yonsei Med J. 2009

[13]. Yamaguchi S., Fujii H, Kaneko S. et al. Ultrasono graphic study in patient with chronic renal failure. Part 1. Ultrasonic measurement of renal size and analysis of renal ultrasonograms. Nippon Hinyokika Gakkai Zasshi, 1990; 81:1175-77. Cited by J Pak Med Assoc.

[14]. Shcherbak Al. Angiographic criteria in the determination of indications for organ preserving surgery in renal artery occlusion. Klin. Khir, 1989;2:5. Cited by Buchholz NP et al. J Pak Med Assoc. 2000.

[15]. Montague JP, Neunschwander S, Dugeut-Lannes MD et al. Renal venous thrombosis in infants. Ultrasonic findings in 7 cases Arch. Fr. Pediatr, 1982; 39:67-8. Cited by J Pak Med Assoc. 2000.

[16]. Sahni D, Jit I, Sodhi L. Weight and measurements of kidneys in northwest Indian adults. Am J Hum Biol. 2001; 13: 726-32. Cited by International Journal of Collaborative Research on Internal Medicine \& Public Health 2012.

[17]. Arooj Adeela, Jostinah Lam, Yeoh J. Wui, Eko Supriyanto. Comparison of Renal Size among Different Ethnicities. International journal of biology and biomedical engineering. 2011: Volume 5, Issue 4: 221-229.

[18]. Saeed Zeb, Waseem Mirza, Raza Sayani, Adil Sheikh, Iffat Yazdani, Syed Ather Hussain. Sonographic Measurement of Renal Dimensions in Adults and its Correlates. International Journal of Collaborative Research on Internal Medicine \& Public Health. 2012; Vol. 4 No. 9:1626-1641. 
[19]. Raza Mujahid, Amina Hameed, M Imran Khan. Ultrasonographic Assessment of Renal Size and Its Correlation with Body Mass Index in Adults without Known Renal Disease. J Ayub Med Coll Abbottabad 2011; 23(3):64-68

[20]. Buchholz NP, Abbas F, Biyabani SR, Afzal M, Talati J, Javed $Q$, Rezvi I. Ultrasonographic renal size in individuals without known renal disease. J Pak Med Assoc. 2000; 50:12-16.

[21]. Dinkel E., M. Ertel, M. Dittrich, H. Peters, M. Berres and $\mathrm{H}$. Schulte-Wissermann. Kidney size in childhood. Sonographical growth charts for kidney length and volume. Pediatr Radiol. 1985; 15:38-43.
[22]. Hekmatnia A., M. Yaraghi. Sonographic Measurement of Absolute and Relative Renal Length in Healthy Isfahani Adults Journal of Research in Medical Sciences 2004; 2: 54-57.

How to cite this article:

Kalpana Purohit, Ankita Purohit, Geeta Satpathy. MEASUREMENT

OF NORMAL KIDNEY LENGTH BY SONOGRAPHY AND ITS

RELATION TO AGE, SEX, AND BODY HABITUS. Int J Anat Res

2017;5(4.3):4668-4673. DOI: 10.16965/ijar.2017.432 